\title{
Chinese Left-behind Women and Children: should they pay for the rural labors' leaving
}

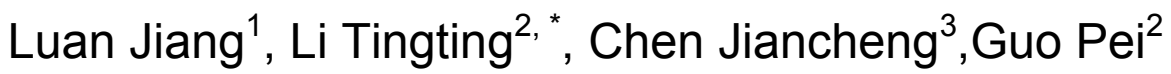 \\ ${ }^{1}$ Department Economics, Party School of CPC Tianjin Municipal Committee, Tianjin, China, \\ ${ }^{2}$ Economic \& Management School,China Agricultural University, Beijing, China \\ ${ }^{3}$ Economic \& Management School, Beijing Forestry University, Beijing, China \\ *Corresponding author; e-mail:csver@qq.com.
}

Keywords: Rural migrants; Spouse and children accompanying

\begin{abstract}
This paper studies the family accompanying behavior of rural migrants in China. It analyzes how the working distance and family population structure affect their spouse and children accompany with them. The working distance and the family population structure exert remarkable efforts to enhance the singleness of rural migrants working alone. We show that the longer working distance the more probability induces the rural migrants to leave home without spouse and children accompany. We also find that the large family surplus population increases the possibility that the spouse and children accompany with them. In particular, this study also indicates that spouse and children accompanying have been gradually improved in recent years in China. Although children accompanying is lagged compare to spouse accompanying, both spouse and child accompanying is increasingly becoming an important transition model of Chinese rural migrants' permanent migration. Besides, the paper illustrates that the employment training and urban education opportunity equity are vital steps to rural migrants' permanent migration.
\end{abstract}

\section{Introduction}

Many Chinese farmers that go to cities alone to earn salary without their spouse and children accompany (Bai and He, 2004; Zhao, 2007). Most of their family members only can meet once or twice a year, namely, rural migrants in China. As a result, nearly 20 million left behind children, 47 million left behind women in rural areas in China, this phenomenon becomes as the breeding bed of a series of new social problems, such as street children and child pornography charges and high divorce rate.

Why do these phenomena appear. This largely is attributed to employment institutions and regulations of labor market are inclined to urban citizen (Cai, 2001). For example, even though rural migrants have worked in the city for many years and had a stable income, they cannot equally access to social security and social welfare and education opportunity that only available for urban residents. Particularly, consider some unavoidable shocks, such as illness, traditional holidays, weddings and funerals and busy farming season and so on, they are subject to go to cities alone without spouse and children accompany with them(De Brauw et al. 2002).

Despite its dramatic growth and increased significance for social stability, the spouse and children accompany of rural migrants has received little attention in academic literature compared to other issues with rural migrants, like for example labor market of rural migrants. Many topics, such as accompany behavior and demography, remain surprisingly poorly understood (Yang, 1999; World bank, 2005).

The reasons are many and varied. One is that any analysis of the spouse and children accompany is handicapped by a lack of readily available information: unlike off-farm workers, little public information is available in farmer household(Cai, 2000). In China, left-behind children are not registered with China's National Bureau of Statistics (NBS), NBS failed to address the issue of left behind children life and health. Another explanation, related to the nature of the one-child policy itself, is that the parents want to protect the confidential/secretive nature of their child number: the second child will let the whole family lose money and lose farm land use right. Another 
complication comes from the fact that the rural migrants have always working in city and have no stable working or living place. Consequently, we cannot get the random sample from the city investigation of them. So city investigation faces a selection bias problem.

We analyze how the working distance and household demography affects the spouse and children accompany with rural migrants, To our knowledge, the current paper is the first empirical one that addresses this issue in spouse and children accompanying of rural migrants. The paper is structured as follows. Related literatures are present in Section2. The model and the assumptions and the date are introduced in Section3. Section 4 analyzes the results. Section 5 concludes the paper.

\section{The Model and Data}

Model and assumption. Consider an accompanying model with working distance and family population structure. The rural migrants want to calculate the net utility if he accept to undertake far away from home work and left behind his spouse and children. For the stake of simplicity, we consider that the rural migrants aim to get money in the city and consume in the rural area. Rural migrants consider a range of economical and social problems that their children and spouse will encounter when they accompany with them. If we assume that the actual net utility of rural migrants' family accompanying is $\mathrm{Ui}$, the minimum expected utility is $\mathrm{U}_{\mathrm{i}}{ }^{*}$, and let Compi denotes the spouses and children accompanying or not. After rural migrants make a comparison between Ui and $U_{i}{ }^{*}$, if he accepts to undertake the outcome of children and spouse accompany and thinks it utility is significantly high than without accompaniment, that is $\mathrm{U}_{\mathrm{i}}>\mathrm{Ui}^{*}$, so compi=1, it means spouses or children accompany with them, otherwise, compi $=0$ means they donot. We describe the decision-making behavior of rural migrants' family accompanying as follows:

$$
\begin{aligned}
\operatorname{prob}\left(\operatorname{Comp}_{i}=1 \mid x_{i}\right) & =\operatorname{Pr}\left(U_{i}>U_{i}^{*} \mid x_{i}\right) \\
& =F\left(x_{i}^{\prime} \beta+u_{i}\right)
\end{aligned}
$$

In order to make the analogy with our empirical application clear, We set model as Probit model in which the main decision is made under a set of affected factors $\mathrm{X}$, a decision must be made under the comparison of utility draw from the distribution of $F()$. For simplicity, we assume that the distribution of $\mathrm{X}$ in the model $\mathrm{F}()$ is the cumulative distribution function of the normal distribution. Our explained variable Compi, then the Expected Value of compi is :

$$
E\left(\text { compi }=1 \mid x_{i}\right)=e^{x_{i} \beta}=E\left(\operatorname{comp}_{i} \mid X_{j}, \mathrm{H}_{c}, Z, \varepsilon_{i}\right)
$$

There are several key factors that we expect should play a role in rural migrants children and spouse accompaniment. We do not exhaustively account for all the determinants of children and spouse accompanying. Neither are we able to test for all the determinants. We attempt to examine how working distance and family surplus population structure relate to children accompanying and spouse accompanying, so we presents the following two hypotheses:

H1: for rural migrants the longer working distance the more probability induces the rural migrants to leave home without spouse and children accompany.

$\mathrm{H} 2$ : for rural migrants the large family surplus population increases the possibility that the spouse and children accompany with them.

In order to examine the two hypotheses, this paper estimates the following regression:

Compi(Children's $)=\beta_{0}+\beta_{1} X_{i}+\beta_{2} \mathrm{H}_{\mathrm{c}}+\beta_{3} Z_{\mathrm{i}}+\varepsilon \mathrm{I}$

Compi(spouse's ) $=\beta_{0}+\beta_{1} X_{i}+\beta_{2} H_{c}+\beta_{3} Z_{i}+\varepsilon I$

Where $\varepsilon i$ is a random error term. The regression focuses on working distance and family surplus population where $\beta_{1}$ is the marginal effect of the degree of children or spouse accompanying. Let $X_{j}$ and $\mathrm{HC}$ denote respectively the job characteristics and individual human capital of thei-th person.

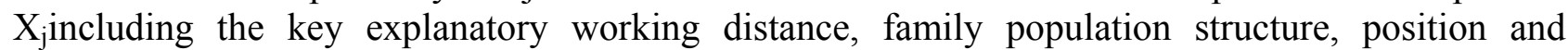
employment category; $\mathrm{H}_{\mathrm{C}}$ is Individual Human Capital, Including quality education, non-agricultural vocational education and professional skills training situations and the non-agricultural work experience); $\mathrm{Z}$ represents personal or family characteristics and other control 
factors (including age, sex, marriage, family size, net assets, social capital and regional dummy variables, etc.).

Data.Our data come from the field survey that carried out in 4 provinces in China from 15 October to 20 November in 2012. It lists, demographics, off-farm work characteristic of rural migrants (including situation of spouse and children accompanying), rural land use right information, family real asset and social capital. The survey interviewed totally 619 peasant households. $46.3 \%$ of sample peasant households engage in non-agricultural employment, $52.7 \%$ of the non-agricultural workers (376 persons) are rural migrant. The telephone interviews actually collect 312 copies of information of them, $82 \%$ respondent.

\section{The results}

In table 1, we report the results of estimating the above equations for spouse and children accompany. From the columns I and II, we see that the working distance and family demographic structure statistically significant, the farther from home they are, the less accompanying, besides, the more family surplus population, the more likely spouse and children go out.

Why the proportion of accompanying in own county is significantly higher than working in the other provinces and other counties in the same province? All these possibilities are plausibly related to a serials cost. For spouse accompanying, working in his own county is close to home, it can not only reduce the cost of living but it's convenient for going back home and taking care of his family. For children accompanying, this problem is closely related to the regional differences and the availability of educational resources. Generally speaking, urban education resources and quality is much better than the countryside. However, there are great difficulties in both social capital and economic strength for rural migrants finding schools for the kids in provincial capital city or developed cities in other provinces. In contrast, it's much easier in his county. Moreover, the county's cost of living is relatively low. 
Table 1 Probit regression results of influencing factors about spouses and children accompanying

\begin{tabular}{|c|c|c|c|c|}
\hline \multirow{2}{*}{ Key variables } & \multicolumn{2}{|c|}{$\begin{array}{c}\text { whether spouse } \\
\text { accompanying }(\mathrm{dF} / \mathrm{dX})\end{array}$} & \multicolumn{2}{|c|}{$\begin{array}{c}\text { whether children } \\
\text { accompanying }(\mathrm{dF} / \mathrm{dX})\end{array}$} \\
\hline & (1) & (2) & (1) & (2) \\
\hline \multicolumn{5}{|l|}{ Characteristic } \\
\hline $\begin{array}{l}\text { Workplace: other county } \\
(1=\text { other county in inside the } \\
\text { province; } 0=\text { others })\end{array}$ & $\begin{array}{c}-0.655 \\
(3.65)^{* * *}\end{array}$ & $\begin{array}{c}-0.777 \\
(4.65)^{* * *}\end{array}$ & $\begin{array}{l}-0.303 \\
(1.66)^{*}\end{array}$ & $\begin{array}{c}-0.444 \\
(2.98) * * *\end{array}$ \\
\hline $\begin{array}{l}\text { Workplace : outside the } \\
\text { province } \\
\text { ( } 1=\text { outside the province; } \\
0=\text { others })\end{array}$ & $\begin{array}{l}-0.091 \\
(0.36)\end{array}$ & $\begin{array}{c}-0.358 \\
(1.96)^{* *}\end{array}$ & $\begin{array}{l}-0.324 \\
(1.58)\end{array}$ & $\begin{array}{c}-0.382 \\
(2.94)^{* * *}\end{array}$ \\
\hline $\begin{array}{l}\text { Remaining member } \\
\text { (person) }\end{array}$ & $\begin{array}{c}0.310 \\
(3.76)^{* * *}\end{array}$ & $\begin{array}{c}0.090 \\
(3.01)^{* * *}\end{array}$ & $\begin{array}{c}0.185 \\
(2.56)^{* *}\end{array}$ & $\begin{array}{c}0.109 \\
(2.03)^{* *}\end{array}$ \\
\hline Number of child (person) & $\begin{array}{c}-0.394 \\
(2.90)^{* * *}\end{array}$ & $\begin{array}{c}-0.167 \\
(2.85)^{* * *}\end{array}$ & $\begin{array}{l}0.117 \\
(0.88)\end{array}$ & $\begin{array}{c}0.232 \\
(1.95)^{*}\end{array}$ \\
\hline Managers $(1=$ yes $; 0=$ no $)$ & $\begin{array}{l}-0.308 \\
(1.81)^{*}\end{array}$ & $\begin{array}{l}0.040 \\
(0.49)\end{array}$ & $\begin{array}{l}-0.148 \\
(0.88)\end{array}$ & $\begin{array}{l}0.187 \\
(1.33)\end{array}$ \\
\hline Self-employed $(1=$ yes $; 0=$ & 0.580 & 0.203 & 0.058 & 0.314 \\
\hline no) & $(3.68) * * *$ & $(3.91)^{* * *}$ & $(0.32)$ & $(1.50)$ \\
\hline $\begin{array}{l}\text { Signed labor contract } \\
\quad(1=\text { yes } ; 0=\text { no })\end{array}$ & $\begin{array}{r}-0.043 \\
(0.19)\end{array}$ & $\begin{array}{c}0.130 \\
(1.92)^{*}\end{array}$ & $\begin{array}{l}-0.213 \\
(1.16)\end{array}$ & $\begin{array}{l}0.030 \\
(0.20)\end{array}$ \\
\hline \multicolumn{5}{|l|}{ Human Capital } \\
\hline $\begin{array}{c}\text { Years of Quality Education } \\
\text { (year) }\end{array}$ & $\begin{array}{l}0.011 \\
(0.42)\end{array}$ & $\begin{array}{c}0.023 \\
(2.00)^{* *}\end{array}$ & $\begin{array}{l}-0.019 \\
(0.76)\end{array}$ & $\begin{array}{l}-0.000 \\
(0.01)\end{array}$ \\
\hline $\begin{array}{l}\text { Received } \\
\text { education } \\
\quad(1=\text { yes } ; 0=\text { no })\end{array}$ & $\begin{array}{c}0.334 \\
(1.77)^{*}\end{array}$ & $\begin{array}{c}0.151 \\
(2.13)^{* *}\end{array}$ & $\begin{array}{l}0.049 \\
(0.29)\end{array}$ & $\begin{array}{l}0.085 \\
(0.59)\end{array}$ \\
\hline Working years (year) & $\begin{array}{c}0.031 \\
(1.72)^{*}\end{array}$ & $\begin{array}{l}0.006 \\
(0.87)\end{array}$ & $\begin{array}{l}0.013 \\
(0.73)\end{array}$ & $\begin{array}{l}-0.013 \\
(0.97)\end{array}$ \\
\hline \multicolumn{5}{|l|}{ Family demographic structure } \\
\hline $\begin{array}{l}\text { Working days per week } \\
\text { (day) }\end{array}$ & $\begin{array}{l}-0.029 \\
(0.28)\end{array}$ & $\begin{array}{l}-0.024 \\
(0.68)\end{array}$ & $\begin{array}{l}-0.079 \\
(0.87)\end{array}$ & $\begin{array}{l}-0.081 \\
(1.20)\end{array}$ \\
\hline Age (year) & $\begin{array}{l}-0.021 \\
(1.46)\end{array}$ & $\begin{array}{r}-0.002 \\
(0.36)\end{array}$ & $\begin{array}{l}-0.013 \\
(0.87)\end{array}$ & $\begin{array}{l}-0.000 \\
(0.04)\end{array}$ \\
\hline Sex $(1=$ male; $0=$ female $)$ & $\begin{array}{l}-0.254 \\
(1.46)\end{array}$ & $\begin{array}{c}-0.132 \\
(2.51)^{* *}\end{array}$ & $\begin{array}{l}-0.254 \\
(1.49)\end{array}$ & $\begin{array}{l}-0.110 \\
(0.66)\end{array}$ \\
\hline $\begin{array}{l}\text { Arable land per capita } \\
\text { (Ha./person) }\end{array}$ & $\begin{array}{l}-0.008 \\
(0.32)\end{array}$ & $\begin{array}{r}-0.005 \\
(0.49)\end{array}$ & $\begin{array}{l}-0.003 \\
(0.12)\end{array}$ & $\begin{array}{r}-0.023 \\
(0.65)\end{array}$ \\
\hline Family net assets (YUAN) & $\begin{array}{l}-0.012 \\
(1.48)\end{array}$ & $\begin{array}{c}-0.014 \\
(3.71)^{* * *}\end{array}$ & $\begin{array}{l}-0.005 \\
(0.56)\end{array}$ & $\begin{array}{c}-0.047 \\
(4.25)^{* * *}\end{array}$ \\
\hline $\begin{array}{l}\text { Number of relatives doing } \\
\text { business } \\
\text { (person) }\end{array}$ & $\begin{array}{l}0.002 \\
(0.06)\end{array}$ & $\begin{array}{l}0.005 \\
(0.30)\end{array}$ & $\begin{array}{c}-0.131 \\
(3.38)^{* * *}\end{array}$ & $\begin{array}{c}-0.162 \\
(5.09)^{* * *}\end{array}$ \\
\hline Observations & 185 & 174 & 165 & 143 \\
\hline
\end{tabular}

Note: 1、Model (1) and (2) respectively control dummy variables of the county and townBecause parameter estimates of Probit model appear completely predict problem when controlling town-dummy variables, some samples will lose automatically, the observations of medel (1) and (2) is different.2、 The parameters of the table are marginal effect of the explanatory variables; 3 . The number of family child is school-age children in the nine-year compulsory stage from 7-16 years old; 4、 It is absolute value of the $\mathrm{Z}$ statistics in parentheses; 5、“*”, “**», “***» respectively denote statistical tests in the $10 \%, 5 \%$ and $1 \%$ significant.

\section{Conclusion}

From the flow patterns of the rural migrants, spouses and children accompanying has become an important transition model of family permanent migration.Although, in recent years,rural migrants' spouses accompanying achieved a great improvement, but children accompanying has improved 
inconspicuously. The main obstacle that child is difficult to accompany is the difficulty of getting urban education resources.Overall, rural migrants are very cautious on family permanent migration.Employees who bring their spouses and children are full of working experience; they usually have a stable job, higher income and relatively young age. At the same time, taking customs, cost of living and convenience into account, the rural migrants prefer bringing their spouses and children to work in the local county, which further highlights the rural immigrants' rational and cautious. Whether spouses and children accompanying have a significant impact on rural migrants' job stability, it is also the key to family permanent migration. Nowadays, in rural migrants, more than $30 \%$ of them get separated with their spouses, and nearly $60 \%$ families have "children left behind",they are all the potential problems of China's urbanization and urban and rural coordinated development. In the long term, relaxing the policy of urban education, increasing infrastructure construction and investment in urban education, ensuring that migrant children have equal right of education are undoubtedly advantageous for rural migrants' family migration.

\section{References}

[1] De, Brauw.; Alan.; Rozelle, Scott.; Linxiu, Zhang.; Jikun, Huang. and Yigang, Zhang.: The Evolution of China's Rural Labor Markets during the Reforms: Rapid, Accelerating, Transforming, Journal of Comparative Economics, No.2, pp.329-353, 2002.

[2] World Bank: China Integration of National Product and Factor Markets: Economic Benefits and Policy Recommendations, World Bank Report,, No.31973-CHA, Washington, D. C., 2005.

[3] Yang, D. and Zhou, H.: Rural-Urban Disparity and Sectoral Labour Allocation in China, Journal of Development Studies, NO.35, pp.105-133, 1999,

[4] Cai Fan:The problem of Chinese migration, Henan People's Publishing House, Henan province, Chinese: 2000.

[5] Cai Fang: Two procession of Chinese migration and the institutional obstacle about it, Sociology study, 2001(4): 46-67.

[6] Bai Nansheng; He Yupeng: Returning to the Countryside versus Continuing to Work in the Cities: A Study on Rural Urban Migrants and Their Return to the Countryside of China, Social Sciences in China, 2004(4): 151-159.

[7] Zhao Zhong: Chinese Migration between Urban and Rural, China Economic Quarterly, 2004(2): 125-158. 